\title{
Influence of Age of Root Stock on Budding Success and Growth of Patch Budded Jackfruit (Artocarpus heterophyllus Lam.) Plants
}

\author{
Archana $^{1 *}$, S. Shyamalamma ${ }^{3}$, Shweta Hiremath ${ }^{5}$, V. Nachegowda ${ }^{2}$, \\ J.S. Aravind Kumar ${ }^{1}$ and A.M. Rajesh ${ }^{1}$ \\ ${ }^{1}$ College of Horticulture, Kolar - 563103, India \\ ${ }^{2} U H S$, Bagalkot, India \\ ${ }^{3}$ Deparment of Biotechnology, UAS, GKVK, Bengaluru, India \\ ${ }^{4}$ Deparmentof Fruit Science, UHS Campus, Bengaluru, India \\ ${ }^{5}$ Deparmentof Fruit Science, KRCCH Campus, Arabhavi, India \\ *Corresponding author
}

\begin{abstract}
A B S T R A C T

\begin{tabular}{|c|}
\hline Keywords \\
\hline $\begin{array}{l}\text { Age, Root stock, } \\
\text { Budding success } \\
\text { Growth, Patch } \\
\text { budded jackfruit }\end{array}$ \\
\hline Article Info \\
\hline $\begin{array}{l}\text { Accepted: } \\
\text { 26 June } 2018 \\
\text { Available Online: } \\
\text { 10 July } 2018\end{array}$ \\
\hline
\end{tabular}

An investigation was carried out to know the effect of age of rootstocks on budding success percentage of jackfruit. Patch budding was done on 2, 4, 6, and 8 months old rootstocks of jackfruit using variety NSP as scion material. The budded plants were kept under open sunlight for four weeks and observed for budding success. Maximum budding success $(90 \%)$, sprouting success $(71.11 \%)$, sprout length $(20.79 \mathrm{~cm})$, number of leaves (11.67) and diameter of bud sprout $(2.89 \mathrm{~mm})$ was recorded on two months old rootstocks followed by four months old rootstocks (budding success (84\%), sprouting success (66.67\%), sprout length $(20.44 \mathrm{~cm})$, number of leaves (11.07) and diameter of bud sprout $(2.75 \mathrm{~mm})$ and six months old rootstocks (budding success $(78 \%)$, sprouting success $(66.67 \%)$, sprout length $(18.16 \mathrm{~cm})$, number of leaves (10.13) and diameter of bud sprout $(2.66 \mathrm{~mm})$. While, minimum budding success was recorded in eight months old rootstocks (budding success $(76 \%)$, sprouting success $(65.79 \%)$, sprout length $(18.55 \mathrm{~cm})$, number of leaves (7.87) and diameter of bud sprout $(2.94 \mathrm{~mm})$. From this study it could be concluded that patch budding using two to four months old rootstocks gave higher budding success in vegetative propagation of jackfruit by budding.
\end{abstract}

\section{Introduction}

The jackfruit (Artocarpus heterophyllus Lam.) belongs to the family Moraceae, is a fairly large sized tree and bears the largest fruit among the edible fruits. Jackfruit tree is native to India and popular in several tropical and sub-tropical countries. Jackfruit serves as a food for millions of poor people in the countryside during the season, where there is a scarcity of food, therefore this fruit is regarded as "poor man's fruit" in Eastern and Southern parts of India and it's the national fruit of Bangladesh. It is quite important both for use as a fruit and vegetable.

The jackfruit tree is widely cultivated in tropical regions of India, Bangladesh, Nepal, 
Sri Lanka, Vietnam, Thailand, Malaysia, Indonesia and the Philippines. Jack tree grows well in humid and warm climate, even on hill slopes. It is also one of the most suitable fruit crop for dryland horticulture. It requires rich, deep and well drained alluvial soil or an open textured loamy or lateritic soil, supplied with adequate moisture and nutrition and grown up to $1500 \mathrm{~m} \mathrm{MSL}$ but the trees grown above $1200 \mathrm{~m}$ MSL produce fruits of inferior quality.

Seed propagation is common method of propagation in jackfruit. But propagation through seeds is not widely accepted because of high heterozygosity. Being highly heterozygous and cross pollinated, it has resulted in immense variation among populations for yield, size, shape, flesh colour, quality of fruit and maturity period. To maintain the genetic uniformity and conservation of an identity of an elite clone or cultivar through vegetative propagation is well recognized in jack fruit. Therefore the elite materials need to be multiplied in large quantities and supplied to the needy farmers. Hence, suitable vegetative propagation technique with suitable age of rootstock is need to be standardized to meet the growing demand of planting material. Keeping these points in view the present study has been undertaken. Radha and Mathew (2007).

\section{Materials and Methods}

The experiment was conducted at Department of Biotechnology, University of Agricultural Science, Bengaluru and College of Horticulture, Kolar. The experiment was laid out in Complete Randomized Block design with five replications. The budding was done on vigorously growing, uniform seedling of 2 , 4, 6 and 8 month old rootstocks were used for budding. The budding operation was done as per the procedure. The observations were recorded on percentage of budding success and bud sprouting success. Observations on
Sprout length $(\mathrm{cm})$, number of leaves per budded plant and diameter of the bud sprout (mm) sprouting from bud were taken at an interval of 15 days.

\section{Results and Discussion}

\section{Budding success percentage}

The effect of age of rootstocks on budding success percentage of jackfruit budded plants differed significantly among the treatments (Table 1). However two month old rootstocks recorded significantly maximum budding success percentage of $90 \%$ followed by four month old rootstock (84\%) and six month old rootstock $(78 \%)$. This could be due to the relationship between age of the rootstock and regenerating ability of the plant. The success was much higher in younger rootstocks as observed by Priyanka (2013). It was found that the percent budding success was more in case of younger rootstocks in comparison to older ones; which could be due to higher activity of meristematic cells, maximum regeneration and callus forming capacity and better union of the bud scion. Ahmad et al., (2007) attributed the higher per cent budding success in case of walnut to rapid union of xylem and cambium tissue of the bud scion and rootstocks or due to much closer matching of the bud scion tissue to the rootstocks stem, which helps in callus tissue differentiation into new cambium tissues. Similar results were noticed by Patel et al., (2007) in guava which they have attributed to the availability of better scion, stock and active sap flow in younger rootstocks. While, minimum budding success was recorded in eight month old rootstock (76\%).The effect of age of rootstocks on budding percentage on jack differed significantly among the treatments. These could be attributed to the latex yielding nature of tree, where more latex exudates in hard wood scions than softwood ones. Further latex contains phenols which are known to 
interfere with auxin synthesis and callus induction.

The data related to effect of age of rootstocks on per cent sprouting success of budded jackfruit plants recorded significant differences among the treatments (Table 2). The maximum percentage of sprouting success $(71.11 \%)$ observed on two month old rootstocks followed by four month $(66.67 \%)$ and six month old rootstock $(66.67 \%)$. The results indicated clearly that, younger the rootstocks, better the sprouting percentage as the age of the rootstocks has a relationship with regenerating ability of a plant which is found to be higher in younger rootstocks and this is because of higher activity of meristematic cells in younger rootstocks resulting in faster formation of callus and quick healing of bud union. It is also evident in this study that, as the age of the rootstocks increased there was reduction in the sprouting percentage which could be due to the lack of intimate contact of cambial region of both stock and the scion bud. These results are in conformity with Aralikatti et al., (2011). Similar results were also obtained in jackfruit budding byNataraj (2013). They opined that the younger rootstocks are better amenable than older ones. Kelaskar (1993) also found similar results in jackfruit. While, minimum budding success percentage was observed on eight months old rootstocks $(65.79 \%)$. As it leads to high latex flow and higher content of phenol reduces the sprouting success. This result was in conformity with Aralikatti et al., (2011) and Nataraj (2013), with lower sprouting success in older rootstock in jackfruit.

\section{Length of bud sprout}

Effect of age of rootstock on sprout length of budded plants showed significant differences among the treatments at different interval after budding (Table 3). Two month old rootstock showed significantly higher sprout length $(5.29 \mathrm{~cm}, 9.00 \mathrm{~cm}, 11.30 \mathrm{~cm}, 18.67 \mathrm{~cm}$ and $20.79 \mathrm{~cm})$ at $60^{\text {th }}, 75^{\text {th }}, 90^{\text {th }}, 105^{\text {th }}$ and $120^{\text {th }}$ day after budding respectively, which was on par with four month old rootstock $(3.78 \mathrm{~cm}$, $7.73 \mathrm{~cm}, 7.97 \mathrm{~cm}, 18.18 \mathrm{~cm}, 20.44 \mathrm{~cm}$ ) at $60^{\text {th }}$, $75^{\text {th }}, 90^{\text {th }}, 105^{\text {th }}$ and $120^{\text {th }}$ day after budding respectively and also on par with six month old rootstock $(7.02 \mathrm{~cm}$ and $16.87 \mathrm{~cm})$ at $75^{\text {th }}$ and $105^{\text {th }}$ day after budding respectively. This could be due to vigorous nature of the younger rootstocks resulting from the faster multiplication of meristematic cells in the juvenile rootstocks. Similar results were obtained in guava by Patel et al., (2007). These results are in conformity with Ghosh (2009) in case of ber where, the maximum length of the budlings noticed on younger rootstocks due to good compatibility between stock and scion bud, which resulted in good vascular connection for movement of water and nutrients from stock to scion. Similar results was obtained in jackfruit by Nataraj (2013).

However lower sprout length $(2.95 \mathrm{~cm}, 6.11$ $\mathrm{cm}, 6.51 \mathrm{~cm}$ and $16.03 \mathrm{~cm}$ ) was recorded in eight month old rootstock at $60^{\text {th }}, 75^{\text {th }}, 90^{\text {th }}$ and $105^{\text {th }}$ day after budding, respectively. This could be due to low meristematic activity and poor connection between stock and scion, resulting in lower length of budded plants. This result was in accordance with Ghosh (2009).

\section{Number of leaves per budded plant}

Effect of age of rootstock on number of leaves per budded plants showed significant differences among the treatments at different interval after budding (Table 4). Two month old rootstock showed significantly higher number of leaves $(2.08,3.38,4.93,7.23$ and 11.67 ) per budded plants at $60^{\text {th }}, 75^{\text {th }}, 90^{\text {th }}, 105^{\text {th }}$ and $120^{\text {th }}$ days after budding respectively, which was on par with four month old 
rootstock $(1.67,3.15,7.05$ and 11.07) at $60^{\text {th }}, 75^{\text {th }}, 105^{\text {th }}$ and $120^{\text {th }}$ day after budding respectively. This might be due to the development of more sprouts, more meristematic activity due to higher cell division, cell elongation and better healing of budded plants. Similar results were obtained Aralikatti et al., (2011) and Nataraj (2013) in jackfruit. The maximum number of leaves per budded plant was noticed in case of guava by
Patel et al., (2007). However lower number of leaves $(1.00,2.73,4.00,5.67$ and 7.87) were recorded in eight month old rootstock at $60^{\text {th }}$, $75^{\text {th }}, 90^{\text {th }}, 105^{\text {th }}$ and $120^{\text {th }}$ day after budding respectively. This could be due to poor meristematic activity, poor content of growth substances and higher phenol activity resulting in lower number of leaves. This result was in conformity with results of Nataraj (2013).

Table.1 Effect of age of rootstocks on budding and sprouting success of budded jackfruit plants

\begin{tabular}{|c|c|c|c|}
\hline Treatments & Budding success $(\%)$ & Sprouting success (\%) \\
\hline $\mathrm{T}_{1}: 2$ Months old rootstock & 90 & $(71.57)$ & $71.11(57.49)$ \\
\hline $\mathrm{T}_{2}: 4$ Months old rootstock & 84 & $(66.42)$ & $66.67(54.74)$ \\
\hline $\mathrm{T}_{3}:$ 6 Months old rootstock & 78 & $(62.03)$ & $66.67(54.74)$ \\
\hline $\mathrm{T}_{4}:$ : Months old rootstock & $76(60.67)$ & $65.79(54.20)$ \\
\hline SEm \pm & $\mathbf{0 . 5 3}$ & $\mathbf{0 . 4 0}$ \\
\hline CD at 5\% & $\mathbf{1 . 5 8}$ & $\mathbf{1 . 2 1}$ \\
\hline
\end{tabular}

Figures in the parenthesis are arc sine transformed value

Table.2 Effect of age of rootstocks on sprout length in budded jackfruit plant at different intervals after budding

\begin{tabular}{|c|c|c|c|c|c|}
\hline \multirow{2}{*}{ Treatments } & \multicolumn{5}{|c|}{ Sprout length $(\mathrm{cm})$} \\
\cline { 2 - 6 } & 60 DAB & $\mathbf{7 5}$ DAB & 90 DAB & $\mathbf{1 0 5}$ DAB & $\mathbf{1 2 0}$ DAB \\
\hline $\mathrm{T}_{1}:$ 2 Months old rootstock & 5.29 & 9.00 & 11.30 & 18.67 & 20.79 \\
\hline $\mathrm{T}_{2}:$ 4 Months old rootstock & 3.78 & 7.73 & 7.97 & 18.18 & 20.44 \\
\hline $\mathrm{T}_{3}:$ 6 Months old rootstock & 3.00 & 7.02 & 7.44 & 16.87 & 18.16 \\
\hline $\mathrm{T}_{4}:$ : Months old rootstock & 2.95 & 6.11 & 6.51 & 16.03 & 18.55 \\
\hline SEm \pm & $\mathbf{0 . 5 7}$ & $\mathbf{0 . 6 7}$ & $\mathbf{1 . 1 3}$ & $\mathbf{0 . 6 2}$ & $\mathbf{0 . 7 3}$ \\
\hline CD at 5\% & $\mathbf{1 . 7 2}$ & $\mathbf{2 . 0 1}$ & $\mathbf{3 . 3 5}$ & $\mathbf{1 . 8 5}$ & $\mathbf{2 . 5 2}$ \\
\hline
\end{tabular}

DAB: Days after budding

Table.3 Effect of age of rootstocks on number of leaves per budded jackfruit plant at different intervals after budding

\begin{tabular}{|c|c|c|c|c|c|}
\hline \multirow{2}{*}{ Treatments } & \multicolumn{5}{|c|}{ Number of leaves } \\
\cline { 2 - 6 } & 60 DAB & $\mathbf{7 5}$ DAB & $\mathbf{9 0}$ DAB & $\mathbf{1 0 5}$ DAB & $\mathbf{1 2 0}$ DAB \\
\hline $\mathrm{T}_{1}:$ 2 Months old rootstock & 2.08 & 3.38 & 4.93 & 7.23 & 11.67 \\
\hline $\mathrm{T}_{2}:$ 4 Months old rootstock & 1.67 & 3.15 & 4.07 & 7.05 & 11.07 \\
\hline $\mathrm{T}_{3}:$ 6 Months old rootstock & 1.47 & 2.96 & 4.00 & 6.38 & 10.13 \\
\hline $\mathrm{T}_{4}:$ 8 Months old rootstock & 1.00 & 2.73 & 4.00 & 5.67 & 7.87 \\
\hline SEm \pm & $\mathbf{0 . 2 4}$ & $\mathbf{0 . 1 5}$ & $\mathbf{0 . 2 1}$ & $\mathbf{0 . 3 8}$ & $\mathbf{0 . 7 2}$ \\
\hline CD at 5\% & $\mathbf{0 . 7 3}$ & $\mathbf{0 . 4 4}$ & $\mathbf{0 . 6 3}$ & $\mathbf{1 . 1 4}$ & $\mathbf{2 . 7 7}$ \\
\hline
\end{tabular}

DAB: Days after budding 
Table.4 Effect of age of rootstocks on diameter of budded jackfruit plants at different intervals after budding

\begin{tabular}{|c|c|c|c|c|c|}
\hline \multirow{2}{*}{ Treatments } & \multicolumn{5}{|c|}{ Diameter $(\mathrm{mm})$} \\
\cline { 2 - 6 } & 60 DAB & $\mathbf{7 5}$ DAB & $\mathbf{9 0}$ DAB & $\mathbf{1 0 5}$ DAB & $\mathbf{1 2 0}$ DAB \\
\hline $\mathrm{T}_{1}:$ 2 Months old rootstock & 2.40 & 2.56 & 2.64 & 2.72 & 2.89 \\
\hline $\mathrm{T}_{2}:$ 4 Months old rootstock & 1.65 & 2.04 & 2.16 & 2.48 & 2.75 \\
\hline $\mathrm{T}_{3}:$ 6 Months old rootstock & 1.11 & 1.96 & 2.22 & 2.56 & 2.66 \\
\hline $\mathrm{T}_{4}:$ 8 Months old rootstock & 1.09 & 2.08 & 2.36 & 2.79 & 2.94 \\
\hline SEm \pm & $\mathbf{0 . 1 3}$ & $\mathbf{0 . 0 6}$ & $\mathbf{0 . 0 6}$ & $\mathbf{0 . 0 7}$ & $\mathbf{0 . 0 6}$ \\
\hline CD at 5\% & $\mathbf{0 . 4 1}$ & $\mathbf{0 . 1 9}$ & $\mathbf{0 . 1 8}$ & $\mathbf{0 . 2 5}$ & $\mathbf{0 . 2 4}$ \\
\hline
\end{tabular}

DAB: Days after budding

Figure.1 Effect of age of root stock on patch budding budded jackfruit (Artocarpus heterophyllus Lam.) plants
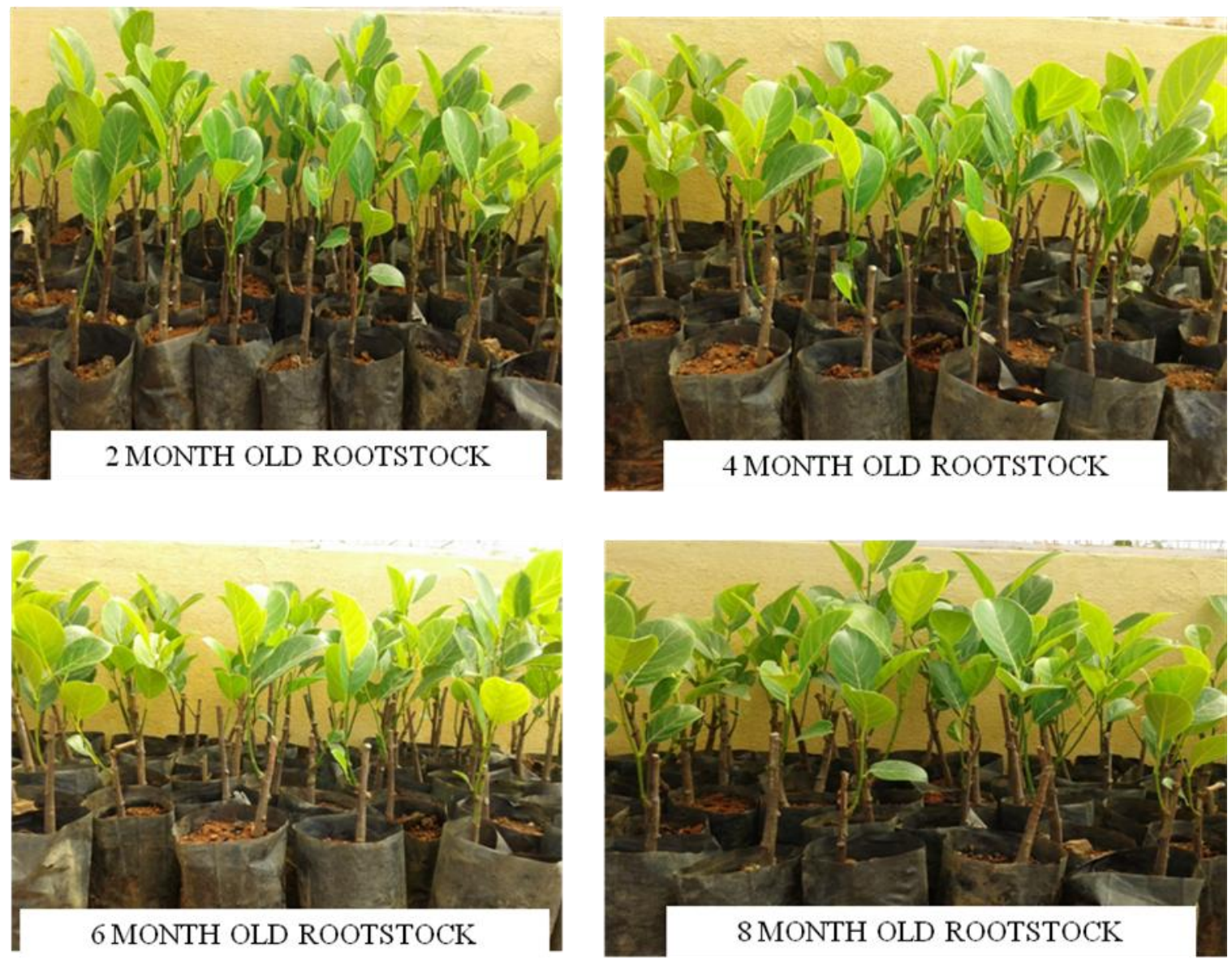

\section{Diameter of bud sprout}

Effect of age of rootstock on diameter of budded plants showed significant result among the treatments at different interval after budding. Two month old rootstocks showed significantly higher $(2.40 \mathrm{~mm}, 2.56$ $\mathrm{mm}, 2.64 \mathrm{~mm}$ and $2.89 \mathrm{~mm}$ ) diameter of budded plants at $75^{\text {th }}, 90^{\text {th }}, 105^{\text {th }}$ and $120^{\text {th }}$ day after budding respectively, followed by four 
month old rootstock $(2.04 \mathrm{~mm}, 2.16 \mathrm{~mm}$, and $2.75 \mathrm{~mm})$ at $75^{\text {th }}, 90^{\text {th }}$ and $120^{\text {th }}$ day after budding respectively. It could be due to younger rootstocks possess higher meristematic activity due to higher rate of cell division and cell elongation, thereby enhances maximum diameter of budded plant. These results are in conformity with Nataraj (2013) in jackfruit. However lower diameter (1.09 $\mathrm{mm}, 1.96 \mathrm{~mm}, 2.22 \mathrm{~mm}, 2.56 \mathrm{~mm}$ and 2.66 $\mathrm{mm}$ ) was recorded in eight month old rootstock at $75^{\text {th }}, 90^{\text {th }}, 105^{\text {th }}$ and $120^{\text {th }}$ day after budding respectively. This might be due to older rootstock may showing poor meristematic activity and cambial activity, which in turn reduces diameter. These results are in accordance with results of Nataraj (2013) in jackfruit.

From these results, it can be concluded that the effect of age of rootstocks on budding percentage on jackfruit differed significantly among the treatments. However, two months old rootstocks significantly recorded the maximum budding success, sprouting success, sprout length, number of leaves and diameter of bud sprout followed by four months old rootstocks and six months old rootstocks. While, minimum budding success was recorded in eight months old rootstock. Therefore patch budding using two to four months old rootstocks gave higher budding success in vegetative propagation of jackfruit.

\section{References}

Ahmad, M., Feza, I. U. and Khan, A. A. 2007. Response of different environments and dates of patch budding on success in walnut. Indian J. Hort., 64 (3): 286289.

Aralikatti, G., Mokashi, A. N., Hegde, R. V., Patil, R. V. and Angadi, S. G. 2011. Softwood grafting in jackfruit. Acta Hort., 890: 101-106.

Ghosh, S. N. 2009. Propagation studies in ber for commercial multiplication in nursery an in situ. Acta Hort., 840: 321-326.

Nataraj, G. 2013. Studies on different age of root stocks and month of budding in gumless jack (Artocarpus heterophyllus Lam.). M.Sc. (Hort.) Thesis, Univ. Hort. Sci., Bagalkot.

Patel, R. K., Yadav, D. S., Singh, A. and Yadav, R. M. 2007. Performance of patch budding on different cultivars/hybrids of guava under mid hills of Meghalaya. Acta Hort.,735: 189- 192.

Priyanka, H. L., 2013, Standardization of grafting techniques in jackfruit. M.Sc. Thesis Univ. Horti. Sci., Bagalkot (India).

Radha, T. and Mathew, L., Text book of Fruit Crops. Horticulture Science Series-3. New India Publishing Agenc, New Delhi, p.325-330.

\section{How to cite this article:}

Archana, S. Shyamalamma, Shweta Hiremath, V. Nachegowda, J.S. Aravind Kumar and A.M. Rajesh. 2018. Influence of Age of Root Stock on Budding Success and Growth of Patch Budded Jackfruit (Artocarpus heterophyllus Lam.) Plants. Int.J.Curr.Microbiol.App.Sci. 7(07): 3826-3831. doi: https://doi.org/10.20546/ijcmas.2018.707.444 